\title{
Arts Education through Coordination with Community and Museum
}

\author{
Shu hua Lin \\ Department of Fine Arts, National Taiwan Normal University, Taiwan \\ y332525@gmail.com
}

\begin{abstract}
This study takes the Lanyang Museum as an example to explore its exhibition strategy and current practice, especially to examine how they operate community art education through the educational programmes.

In this essay, method of semi-structure depth interview, literature review are applied to examine how the museum coordinates with art education. Mthod of questionnaire survey is taken to understand audience's responses to museum administration and exhibitions and displays. Course structures are analyzed and special exhibition strategies and museum educational programmes are evaluated.

Educational programmes designed by the museum staffs in coordinating with school art teachers, artists, and volunteers help to break boundaries of subjects learning and generation level in both museum and school education. Obviously, community art education enforces dynamic of cultural growth and lifelong learning.

This essay finds that a good museum exhibition strategy can improve quality of art education if a corporation partnership is established. Museum helps to create close relationship between audience, student and museum itself.
\end{abstract}

Index Terms - art education, community, Taiwan, lifelong learning

\section{Introduction}

Lanyang Museum, located in the northeastern part of Taiwan, is a good example of an ecomuseum that plays an important role in educational process. Owing to the isolation in geography, Lanyang area maintains great landscapes of natural beauty and simplicity. Significantly, people of this area are culturally devoted to inheriting their ancestors' living manners and traditions. All of these matters converge to make Yilan County a living model in history of the development of Taiwan. It provides the audiences with opportunity to experience the unity of culture and arts. Its exhibition design instills understanding of cultural ecology and collective memories of history into audiences' minds. Growing up from a small local community, Lanyang Ecomuseum seeks to promote cultural activities and ambitiously makes itself a central hub for culture and art learning in Yilan County. It can be seen as a representative in the history of area development of the Lanyang Plain.

The ideas of community museum and ecomuseum were introduced into Taiwan and greatly impacted the ideas of museums in late twentieth century. The 1990s was the watershed that divided the history of museum development into two parts. The type of community museum was seen popular before 1990. Museums of this type served to provide exhibitions and education programmes to people from local community. On the other hand, an ecomuseum develops from local museum and engages business that concerns broad social and cultural activities beyond the capacity of local community museum. Owing to the strong sense of political and cultural identity grown in Yilan County, community museum was seen most flourishing among various counties in Taiwan.

Yilan as a self-expected cultural county started to draft the plan for founding the Lanyang Museum in 1991. It was designed to take the culture of Yilan County as the theme of this museum. Inviting public participation in the museum is the core idea in running the Lanyang Museum.

After a long time of delay, caused by hesitation in decision-making on solving the problems of the museum construction and preparatory process, the Lanyang Museum was formally opened in 2010. Before the Museum was ready for open, the committee started to work out some plans to integrate museum resources in Yilan County under the guideline that museums exist in this county must work under the ideas of the ecomuseum. This new idea of museum administration worked out in this new institution was named "Yiland County Museum Family". The Museum Family includes members of public and private museums. They seek to integrate historical, natural, and cultural resources in communities to create the so called the 'ecomuseums' for people of the Yilan County. In this sense, cultural activity will therefore be a combination of social and economic development as well as peoples' living manners and natural environment of Yilan County.

\section{Literary Review}

The concept of ecomuseum was firstly discussed by French scholars Georges Henri Rivière and Hugues de Varine in the 1970s. They introduced the idea of ecology (human and nature ) and regional ideas into museum studies. In Taiwan, the notion of ecomuseum was widely welcomed because the richness of cultural activities is ready to be available. Regional council governments are encouraged by public sectors and the audiences to established their special features and indigenous cultural diversities. In policy making over the questions of the nature and the mission of an ecomuseum, most regional council governments are rich in cultural property and legend of cultural tradition. The cultural legends can be found in ways of living manner, rites and festivals people practice as a routine in years after years. They became valuable attractions and resources for tourism industry, and furthermore, became valuable content for founding an ecomuseum. The more the regional council government involves with shaping a cultural 
identity, the more the discourses and notions of an ecomuseum are introduced.

To Rivière and de Varine, the entity of an ecomuseum is no longer limited to a specific museum building. An ecomuseum can be run by organizations, using a divergent network system connecting the core museum and satellite or quasi-museums to enlarge the boundary of the museum to the whole village, school, natural conservation area, and even to the whole nation. The fundamental mission of the museum will be no longer limited to collections, exhibition and

education. The outreach resources of nature and heritage will be included in the ecomuseum. As a result, an ecomuseum is in an extending situation both in dimension and content but not a convergent or limited one. The numbers of museum goers hence increased and grew up steady in recent years in Yilan County. Taking Yilan as an example, one may find out that using the notion of maintaining an ecomuseum has been widely introduced to improve diversity of museum administration by local government.

Ecomuseum helps local residents to rediscover the identity of themselves, and to understand how their ancestors in different time and space had made efforts in keeping their ways of live as a mirror to illuminate the culture that belongs to the homeland. It offers the audiences better opportunities, and functions as a mirror, to understand the cultural industry, living manner, and identity of communities. Based on this observation, an ecomuseum may be suitable for audience of various levels. The dialogues on experience of live and sense of history between people of this area also become possible. And the conversation of such life experiences becomes the resource that reinvigorates culture of the area.

One of the functions of the ecomuseum is to break the boundary between the Museum and the community. As an institution, the ecomuseum embraces the community and the environment as a whole to be the core value in museum administration. The place of the community, where the main museum located, and the whole environment settings are regarded as the boundary of the ecomuseum. A specific museum building and a certain amount of collections are not necessary needed in running an ecomuseum.

\section{Methodologies}

This research applies the methods of semi-structure depth interview and literature review to examine how the museum and the community coordinate with art education. Method of questionnaire survey is also taken to examine how audiences response to museum administration, exhibitions and displays. Course structures of school arts are analyzed; and, special exhibition strategies and museum educational programmes are evaluated.

The research methods applied in this essay are effective in understanding the museum exhibition strategy and the meaning of strategic planning of Lanyang Museum. And, through the implementation of the adult audience interviews, this essay aims to understand the ideas of the audiences about museum education programs. By these ways to organize the exhibition strategies and implementation methods, and also proposed the possible problems and solutions. So it can be used as a reference for the future exhibition planning.

The Individual and the group visitors are invited to give their opinions about the museum exhibition and administration. The audiences selected for taking questionnaire survey are picked up by random. Some senior museum visitors who are illiterate or not be able to communicate in Chinese Mandarin are provided with translations. The pool covers various age levels and professions.

\section{Case Study: Arts Education through Coordination between Community and Museum}

This study aims to explore the case of art education undertaking through community and educational programmes of the Lanyang Museum. As the forerunner of ecomuseum, Lanyang Museum was designed to embrace culture, history and ecology of this specific county. It provides vast opportunity to promote community arts education through museum coordination.

The Preparatory Office of the Lanyang Museum was an organization that belongs to the public sector. It was then collaborated with the individuals from private sectors to work out as a team. The team members work together in a type of informal family meeting to discuss about the missions and the administrations among the museum family. In 2001, the Association of Museum Family of Yilan County was established under the supervision of the county government. This Association was an organization made up of people work for public and private sectors.

In the beginning of its planning for establishing this museum in the 1990s, Lanyang Museum set forth from the idea that this museum must be the core museum which receives supports from groups of community museums that work as satellite museums. The core museum can be supported by the public sector in the government. However, the satellite museums offer opportunity for community participation and curate subject exhibitions.

Lanyang Museum is a show window that provides good access for the audiences. It took strategies to enforce the concept of ecomueum, such as mobilized people to acquire objects for collection, conducted interactive research, design exhibitions in way of representing daily life for education, and introduce industrialization to museum management. These strategies were expected to back up conservation of cultural heritage and tourism industry of Yilan County. It is therefore that Lanyang Museum focuses on promoting the characteristic of being 'local' Yilan through collecting, researching, displaying, and marketing and inheriting culture of Yilan. Hopefully, Yilan would be a happy land for education, tourism and leisure recreation.

Let me move a bit to a discussion on education itself before I move back to the museum coordinative education. The notion that arts learning can be improved through greater access, more-equitable access, better-quality provision, or more-efficient provision has been discussed by Scholars. In history of art education in Taiwan, main theories of art 
education has been introduced into school education from Western scholars.

As researcher pointed out, the arts have long been treated as essentially different from and often been regarded as secondary to other school subjects. Taking Taiwan for example, the budget for conducting art education out side regular art class shares only tiny part of the annual budget for education in central government.

The course structures were reshaped and intended to be working with community and museums. In fact, the integrated missions are also legislated in acts and laws of the Ministry of Culture that give direct supervision on Bureau of Cultural Affairs of local government like Yilan County.

As a result, owing to the curriculum reform, traditional purposes of art education such as to teach mastery of an art form becomes less important. Instead, to cultivate understanding and appreciation of the art field, to develop various life skills become the core idea in art education. Taiwan might be not alone in making policy for art education in this key tone.

As researcher points out, from appearance alone, doing coordination between organizations within the public sector may benefit each part of them. It is especially needed when each of these organizations has an important shared goal, or each of them individually lacks the political power or resources to achieve its goal on its own. However, we needed to understand what a coordinated effort to improve arts education might be useful, and why coordination might be a good strategy for effecting improvement, as Purnell argues.

Lanyang Museum organizes exhibition spaces into three floors, embracing collection objects originally growing from the mountains, the plains, and coming from the ocean. This way of display symbolizes a paradigm idea of the geography of Yilan County as a whole, from the mountain to the ocean. There are beautiful mountains and agricultural farmlands in the west rim of the Pacific Ocean.

Let me move back to the case study of Lanyang Museum. In Lanyang Museum, they explored arts integration programs in which teachers and artists worked together to design lessons that connect subject content and the arts. Students benefit from cultural diversity and learn arts from their cultural contexts. The results indicate that associations with gains across the curriculum, including museum guidance, drawing lessons, folk music and dance help students to learn arts from lives of their ancestors.

Community art education conducted in Lanyang Museum offers opportunity to reexamine educational value of artsbased learning from the museum. It breaks the narrow focus on academic outcomes and myth of mastery in art making. Admission to the ecomuseum for senior citizens residing in Lanyang is free. People are encouraged to learn about the environment from which they grow up. According to a questionnaire, more than $70 \%$ of senior citizens who have visited Lanyang Museum found themselves better understanding the culture and art of the Lanyang area.

\section{Findings and Conclusion}

For a long time, Museum and school art education have jointly promoted the idea of collaboration. By combining public and private museums, as well as horizontal integration of resources, it is expected that school art education can be brought up to a new stage of efficiency.

This research finds out that a good museum exhibition strategy can improve quality of art education if a corporation partnership is established. Museum helps to create better relationships between audience, student and museum itself. It also shares exhibition experience and knowledge of curatorial practice with those who work with museum in academic purposes. In special exhibitions, held under sponsorship of great media company, museum plays an important role as promoter in designing educational program for volunteers and school art teacher training. In Taiwan, museum's social and educational functions have been elevated to a more significant position than before. Public opinions about creating cultural diversity are welcomed by museums. The connections between museum exhibitions, community engagements, and school outreach activities are valued highly in overall museum assessment. This essay suggests possibilities to the public sector in museum management to consider about a cooperative relationship between experts, residents and governments in museum management and to promote museum and community arts education.

\section{References}

[1] Lu, Li-cheng (2006). Lanyang as a museum, my view on the prospect of Lanyang Museum, e-journal of Lanyang Museum, Dec. 2006.

[2] Lee, Meng-Hsuan(2011). The Strategy and Practice of Exhibition of Lanyang Museum. MA. Dissertation. National Taiwan Normal University, 2011.

[3] Chang, Li-Ling (1998). The Study on Eco-museum and Development of Regional Culture--the Case of Lan-Yang Museum. MA. Dissertation. National College of Arts, 1998.

[4] Chang, Yu-Teng (1996). Eco-museum of the planning rationale and case analysis. Museology Quarterly.10(1): 7-18.

[5] Chang, Yu-Teng (2005). Ecomuseum: the rise of cultural revolution. Taipei, Wooguan publication Co.

[6] Chang, Yu-Teng (2010). When the local encounters Museum: Symposium on Taiwan experience and interdisciplinary culture. Lanyang Museum.

[7] Liu, Cheng-Hui (2009). Redevelopment in Houdon area: Vision of Ecomuseum. Conference paper, Annual Research Conference.

[8] Hsin-Yi-Lo (2010). When the local encounters Museum: The history of development in Yilan County and Taiwan. Symposium on Taiwan experience and interdisciplinary culture. Lanyang Museum.

[9] Hsin-Yi Lo (2011) Museums and Cultural Policies: A Study on Taiwan Museums' Policies and Development after 1990s. Ph.D. Dissertation. 2011.

[10] Chen, Jia-Li (2003). Movement of Community Museum: a global vision. Musecology Quarterly, 18(4): 43 57.

[11] Bodilly, Susan J., Augustine, Catherine H., with Zakaras, Laura. (2006) Commissioned by Revitalizing Arts Education Through CommunityWide Coordination. Sata Monica, CA. RAND Corporation.

[12] Retrieved 2012 Feb 14, 2013, from http://www.rand.org/content/dam/rand/pubs/monographs/2008/RAND_ MG702.pdfRevitalizing

[13] Purnell, Paula G. (2008). The Collaboration of teacher / artist teams: a qualative analysis of selected international components influencing a partnership-model artist residency. Indiana University of Pennsylvania. Retrieved Feb 14, 2013, from 
http://dspace.iup.edu/bitstream/handle/2069/84/Paula\%20Purnell.pdf?se quence $=1$

[14] Rivière, G. H., (1985), "The ecomuseum - an evolutive definition." Museum 37(4): 182-183.

[15] Bodilly, Susan J., Augustine, Catherine H., with Zakaras, Laura. (2006) Commissioned by Revitalizing Arts Education Through CommunityWide Coordination. Sata Monica, CA. RAND Corporation. Retrieved 2012 Feb 14, 2013, from
http://www.rand.org/content/dam/rand/pubs/monographs/2008/RAND MG702.pdfRevitalizing

[16] Purnell, Paula G. (2008). The Collaboration of teacher / artist teams: a qualative analysis of selected international components influencing a partnership-model artist residency. Indiana University of Pennsylvania. Retrieved Feb 14, 2013, from

http://dspace.iup.edu/bitstream/handle/2069/84/Paula\%20Purnell.pdf?se quence $=1$ 